\title{
CURCUMIN PROTECTION AGAINST CADMIUM CHLORIDE-INDUCED BIOCHEMICAL ALTERATIONS IN LUNGS OF SWISS ALBINO MICE
}

\author{
AMRITA KUMARI*, SUMAN SHARMA \\ Department of Zoology and Environmental Sciences, Punjabi University, Patiala, Punjab, India. Email: amritasim16@gmail.com
}

Received: 06 March 2020, Revised and Accepted: 10 April 2020

ABSTRACT

Objective: The aim of the present study was to investigate the protective effect of curcumin against cadmium chloride $\left(\mathrm{CdCl}_{2}\right)$-induced toxicity in lungs of albino mice.

Methods: Albino mice were divided into eight groups and five mice were kept in each group. The experiment was carried out for 15 and 45 days. Group 1 mice were kept as control. Group 2 mice were given an oral dose of $1 \mathrm{mg} / \mathrm{kg}$ body weight of cadmium chloride on alternate days. Group 3 mice were administered an oral dose of $1 \mathrm{mg} / \mathrm{kg}$ body weight of cadmium chloride on alternate days and $100 \mathrm{mg} / \mathrm{kg}$ body weight of curcumin daily. Group 4 mice were received an oral dose of $100 \mathrm{mg} / \mathrm{kg}$ body weight of curcumin daily. Autopsies were done on 15 and 45 days post-treatment.

Results: The results of the present study showed a significant decrease in organ weight at both the intervals. Biochemical analysis showed decline in total glycogen, cholesterol, and protein concentration in lung of cadmium chloride-treated mice. Furthermore, the cadmium chloride concentration in cadmium chloride-treated group was increased in comparison to the control group. However, the treatment with curcumin ameliorated cadmium chloride-induced changes in lung tissue as it instigated the antioxidant enzymes remarkably. However, cotreatment of cadmium chloride with curcumin boosted the changes due to cadmium chloride.

Conclusion: Hence, we concluded that curcumin has protective efficacy in the lungs against the cadmium chloride generated toxicity in albino mice.

Keywords: Cadmium chloride, Curcumin, Protective, Oxidative stress, Pollutant.

(c) 2020 The Authors. Published by Innovare Academic Sciences Pvt Ltd. This is an open access article under the CC BY license (http://creativecommons. org/licenses/by/4. 0/) DOI: http://dx.doi.org/10.22159/ajpcr.2020.v13i6.37463

\section{INTRODUCTION}

Cadmium (Cd) is one of the most occurring industrial and environmental pollutants. Cd is a soft, silver-white in metallic form [1]. Cd ranks seventh on Agency for Toxic Substances and Disease Registry (ATSDR)/EPA list of hazardous substances [2] and has been classified as Group I carcinogen by International Agency for Research on Cancer [3]. Moreover, the United States Environmental Protection Agency considers cadmium to be a Class B1 carcinogen [4]. The California Safe Drinking Water and Toxic Enforcement Act of 1986 (Proposition 65) has listed "cadmium and cadmium compounds" on the Proposition 65 list as carcinogens [5]. Furthermore, Cd is described as developmental toxicant and as a male reproductive toxicant [5].

Humans are exposed to $\mathrm{Cd}$ more by ingestion than inhalation [6]. Inhalation of Cd can occur in smokers or the people who are in occupational exposure [7]. According to the size of the particle, solubility of Cd compound inhaled and duration of exposure, absorption of $\mathrm{Cd}$ ranges from $10 \%$ to $50 \%$ in lungs [8]. Cigarette smoke is a big source of $\mathrm{Cd}$ to both smokers and non-smokers. One cigarette contains $2.0 \mu \mathrm{g}$ of Cd, of which $2-10 \%$ is transported to cigarette smoke [9].

Cd causes tissue injury through oxidative stress. Cd stimulates the production of intracellular reactive oxygen species through mitochondrial electron transport chain retardation [10]. According to ATSDR [11], Cd led to the development of chronic obstructive pulmonary disease in smokers. Inhaling $\mathrm{Cd}$ for long duration may cause lung cancer $[12,13]$. Cd may also lead to a wide range of physiological, biochemical, and behavioral dysfunctions [14].

Curcumin (diferuloylmethane) is an active, yellow-colored component obtained from rhizomes of turmeric, Curcuma longa Linn. and a herb in ginger family (family Zingiberaceae) [15]. The scavenging and trapping potential of curcumin can be attributed to their chain breaking activity by donating hydrogen atoms probably from their phenol $(\mathrm{OH})$ groups. Thus, curcumin affords protection against oxidative agents in brain, liver, lungs, kidneys, and heart [16].

Heavy metals are constant and global pollutants that generate oxidative stress and thus affecting structure and function of various organs of body. As curcumin has medicinal properties, it can be used as a protective agent against $\mathrm{CdCl}_{2}$-induced oxidative stress in lungs of albino mice.

\section{METHODS}

\section{Animals}

Albino mice having weight of 20-22 g were obtained from Central Research Institute, Kasauli. They were acclimatized for 10-15 days and given standard pellet diet (obtained from Hindustan Liver Limited, Mumbai, India) and RO water ad libitum. The animals were handled with proper human care in accordance with the guidelines of the Institutional Animal Ethical Committee.

\section{Chemicals}

Cd chloride $\left(\mathrm{CdCl}_{2}\right)$ and curcumin were purchased from HiMedia Laboratories Pvt., Ltd., Mumbai. $\mathrm{CdCl}_{2}$ was dissolved in distilled water and was administered to mice orally. An aqueous suspension of curcumin was made [17] and administered orally to mice.

\section{Experimental design}

Mice were divided into the following eight groups:

Group 1 mice were kept as control and were given RO water along with pellet diet. Group 2 mice were received $1 \mathrm{mg} / \mathrm{kg}$ body weight of $\mathrm{CdCl}_{2}$ orally on alternate days for 15 days. Group 3 mice were given $1 \mathrm{mg} / \mathrm{kg}$ 
body weight of $\mathrm{CdCl}_{2}$ on alternate days and $100 \mathrm{mg} / \mathrm{kg}$ body weight of curcumin daily orally for 15 days. Group 4 mice were given an oral dose of $100 \mathrm{mg} / \mathrm{kg}$ body weight of curcumin daily and were kept as positive control for 15 days.

Similar experiment was carried out for 45 days also: Groups 5, 6,7 , and 8 , respectively. Autopsies were done on 15 and 45 days post-treatment. Body weights of both the controlled and treated mice were recorded before, during, and after treatment. After that animals were sacrificed, the lung tissue was removed, freed of adipose tissue, blotted dry, weighed, and was processed for biochemical analysis.

\section{Biochemical studies}

Lung homogenate was prepared with the help of tissue homogenizer in $3 \mathrm{ml}$ of phosphate buffer and used for the estimation of glycogen from tissue extract with the method of Montgomery [18], cholesterol was assessed by the method of Zlatkis et al. [19], and protein by the method of Lowery et al. [20]. Cd content from the lungs tissue was estimated by the method of Ballantine and Barford [21].

\section{Statistical analysis}

The data were analyzed using the Student's t-test and Two way ANOVA.

\section{RESULTS AND DISCUSSION}

\section{Organ weight}

A significant $(p<0.0001)$ reduction in weight of lungs was observed at 15 days and 45 days in Cd-treated Group II and Group VI in comparison to the control group of mice I and V. Cd+Curcumin treated Group III and Group VII also showed significantly decreased $(\mathrm{p}<0.001)$ lungs weight as compared to the control groups. Whereas, curcumin-treated Groups IV and VIII showed no significant change ( $p>0.05)$ in weight of lungs at 15 and 45 days post-treatment in comparison to the control groups (Fig. 1).

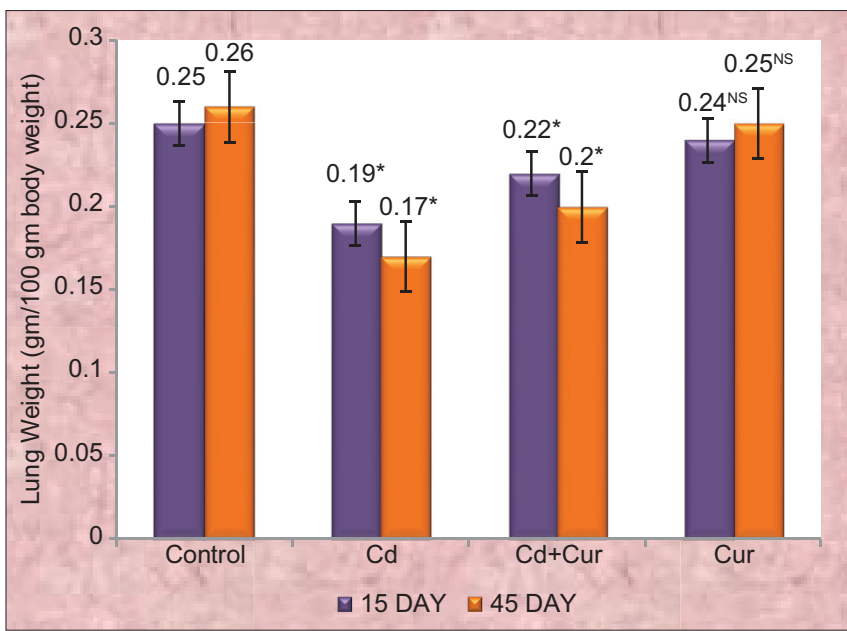

Fig. 1: Weight of lungs in control, Cd, Cd+Cur and, Curtreated groups of mice. Values are given as mean \pm SEM from five mice in each group. (*Significant, NS: Non-significant) (Curcumin=Cur)

\section{Total glycogen content}

In this study, glycogen content in lungs was found to be significantly decreased $(p<0.0001)$ at both the intervals in Groups II and VI. Groups III and VII also showed significantly decreased $(\mathrm{p}<0.001)$ glycogen level in lungs at both intervals. Whereas, Groups IV and VIII showed non-significant $(p>0.05)$ decrease in glycogen content in comparison to control Groups I and V (Fig. 2).

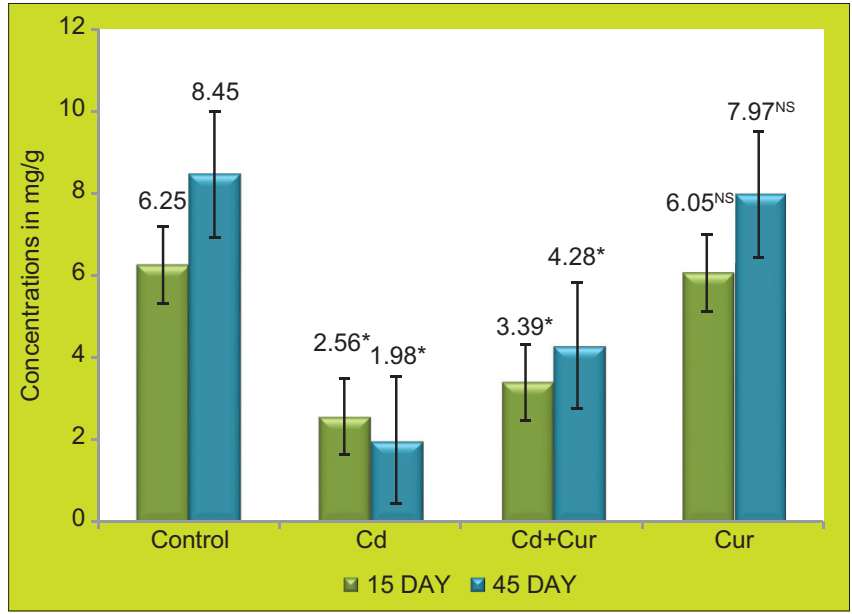

Fig. 2: Total glycogen content of lungs in control, $\mathrm{Cd}, \mathrm{Cd}+\mathrm{Cur}$, and Cur-treated groups of mice. Values are given as mean \pm SEM from five mice in each group. (*Significant, NS: Non-significant) (Curcumin=Cur)

\section{Total cholesterol}

Total cholesterol content was observed to be significantly decreased $(\mathrm{p}<0.0001)$ in lungs in Cd-treated Groups II and VI in comparison to control Groups I and V. There was a significant decrease $(\mathrm{p}<0.001)$ in total cholesterol in Groups III and VII at both intervals. Group IV showed non-significant decrease $(\mathrm{p}>0.05)$ and Group VIII showed significant increase $(\mathrm{p}<0.01)$ in total cholesterol as compared to the control Groups I and V (Fig. 3).

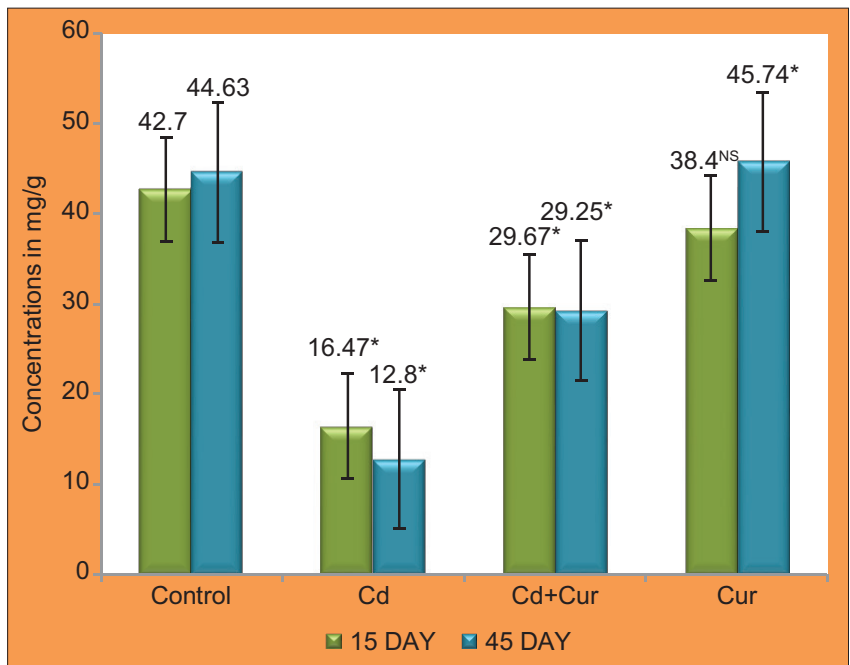

Fig. 3: Total cholesterol content of lungs in control, $\mathrm{Cd}, \mathrm{Cd}+\mathrm{Cur}$, and Cur-treated groups of mice. Values are given as mean \pm SEM from five mice in each group. ( ${ }^{*}$ Significant, NS: Non-significant) (Curcumin $=$ Cur)

\section{Total protein content}

Total protein concentration was found to be significantly reduced $(\mathrm{p}<0.001)$ in lungs in Cd treated groups II and VI in comparison to control group I and V. Group III $(p>0.05)$ and VII $(p<0.001)$ also showed significantly decreased total protein level in comparison to control groups. Group IV and Group VIII showed non-significant $(p>0.05)$ decrease in protein content as compared to Group I and V mice (Fig. 4) 


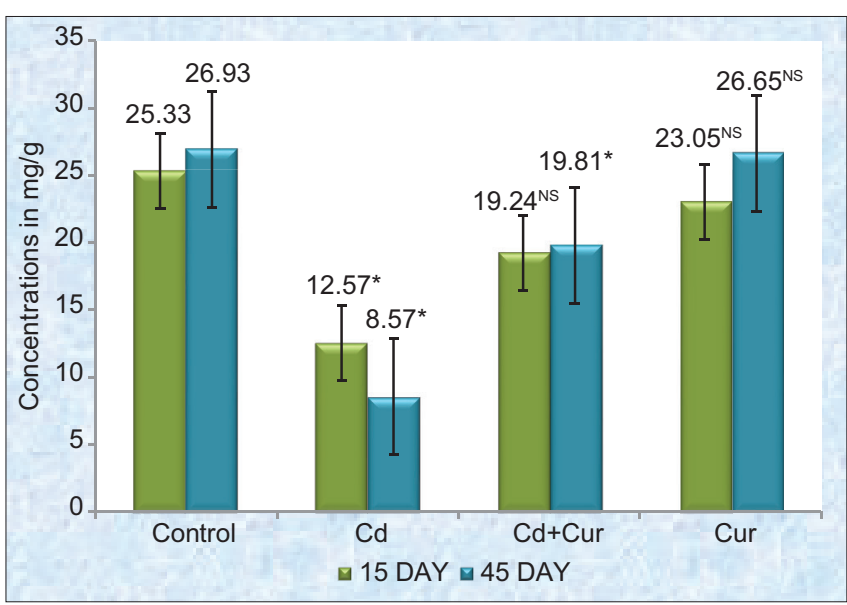

Fig. 4: Total protein of content of lungs in control, $\mathrm{Cd}, \mathrm{Cd}+\mathrm{Cur}$, and Cur-treated groups of mice. Values are given as mean \pm SEM from five mice in each group. ( ${ }^{*}$ Significant, NS: Non-significant) (Curcumin=Cur)

\section{Cd content in lungs}

In the present study, no Cd was detected in group I, IV, V and VIII. However, the level of $\mathrm{Cd}$ was found to be significantly more in $\mathrm{Cd}$ treated groups II and VI as compared to control group in lungs. However, a significant $(\mathrm{p}<0.0001)$ decrease in concentration of Cd was seen in Group III, IV, VII and VIII as compared to Cd treated Group II and VI (Fig. 5).

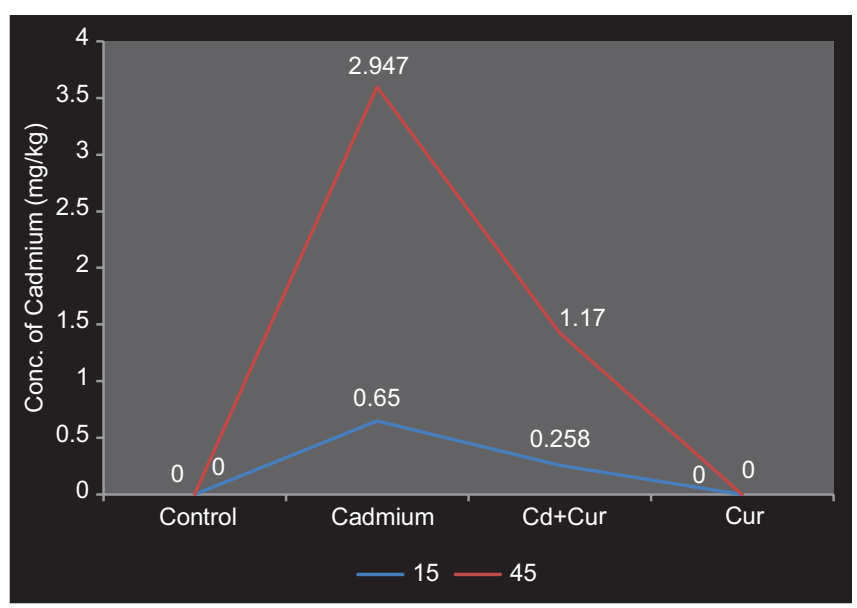

Fig. 5: Cd content of lungs in control, $\mathrm{Cd}, \mathrm{Cd}+\mathrm{Cur}$, and Cur-treated groups of mice. Values are given as mean \pm SEM from five mice in each group. ( ${ }^{* S i g n i f i c a n t, ~ N S: ~ N o n-s i g n i f i c a n t) ~(C u r c u m i n=C u r) ~}$

\section{DISCUSSION}

The effect on body weight and organ weight is one of the main symptoms of toxicological damage $[22,23]$. This reduced organ weight may be linked to the damaging effects of $\mathrm{Cd}$ on lung tissue. In animal studies, weight of organs can be taken into notice to evaluate the metal toxicity [24]. Curcumin due to its antioxidant and dopaminergic activities balances the body weight in rats [25]. Similar preventive action of curcumin by maintaining body weight of mice and rats is also reported by many other authors [26-28]. Similarly, it also reported decrease in body weight and attributed it to reduced digestion and absorption of nutrients [29] and consumption of less food and water [30] due to loss of appetite. These can be linked to the reduced lungs weight due to $\mathrm{Cd}$ intoxication.

Glycogen is a vital source of energy for the general metabolism of body [31]. Decrease in glycogen content is in agreement with the studies of other authors [32-38]. It was proposed that insulin decreases the blood glucose level by enhancing the sugar membrane transport and also by increasing the conversion of glucose into glycogen and triglycerides, therefore decreases the liver glucose production [39]. It was described that enhanced catabolism of biomolecules or less synthesis of biomolecules could be the reason of changes in the glycogen concentration [40]. Stress or less intake of food leads to higher level of stress hormones (cortisol/adrenaline) in blood which brings about depletion of glycogen and hence decline in glycogen content [41]. Curcumin enhances the glucokinase activity and glycogen content, however, it decreases the G6Pase and PEPCK activities. It was also reported that curcumin inhibited the activities of gluconeogenic enzymes and upregulated the glycolytic enzymes, which led to reduction in glucose concentration and hence glycogen content in mice [42].

Decrease in cholesterol content in Cd-treated group is in agreement with the work of other authors $[35,37,38,43]$. Reduced cholesterol level may be linked to its increased consumption in corticosteroidogenesis and/or its de novo synthesis [44]. Thyroid hormones might also be involved in cholesterol metabolism and its increased breakdown in hyperthyroidism can cause hypocholesterolemia [45].

Reduced protein content was observed in Cd-treated group. Some authors also reported similar trend in their research findings $[37,38,43,46-49]$. It was suggested that decline in protein content may be due to reduced level of synthesis of protein or enhanced consumption of proteins [50]. Undesirable conditions such as inaccessibility of important enzymes and/or reduced protein synthesis sites lead to less protein synthesis [51]. Author also explained that the declined protein concentration could be due to disrupted protein metabolism and/ or changed physiology and might be due to the stress of toxicant [52]. It was suggested that reduced protein concentration could be due to catabolism of protein and/ or hepatic malfunction [53].

Curcumin ameliorated the toxicity induced by $\mathrm{Cd}$ by increasing the level of proteins in lungs. It was reported the therapeutic efficacy of Curcumin in enhancing the protein synthesis and reviving the damaged liver tissue [54]. This study is also in agreement with the findings of another author [55]. It was also reported that Curcumin increased the protein concentration due to its antioxidant property and also counterbalances the damaging effects of $\mathrm{Cd}$ toxicity in mice [56].

Eybl et al. [55] suggested that curcumin administration leads to declined $\mathrm{Cd}$ accumulation in the tissues of mice. They also proposed that $\mathrm{Cd}$ load may be declined by curcumin through metal-ligand interaction between $\mathrm{Cd}$ and curcumin. This is in agreement with the observations of other researchers [57-59].

Curcumin decreases the $\mathrm{Cd}$ accumulation in the organs certainly through its chelating activity. Curcumin might disturb the gastrointestinal absorption of $\mathrm{Cd}$, therefore causing a reduced $\mathrm{Cd}$ concentration in the blood and tissues [60].

\section{CONCLUSION}

Based on the explained data, we conclude that $\mathrm{Cd}$ is a toxic chemical that produced significant toxic effects in lungs of treated mice as revealed by the severely affected parameters. Furthermore, this investigation fundamentally cleared the protective and/or ameliorative role played by curcumin as it normalizes the biochemical parameters disturbance caused by Cd.

\section{ACKNOWLEDGMENT}

The authors gratefully acknowledge the facilities provided by the Department of Zoology and Environmental Sciences, Punjabi University, Patiala, Punjab, India, to pursue the research work and also the Institutional Ethical Committee for permitting to work on mice. 


\section{AUTHORS' CONTRIBUTIONS}

Both the authors have contributed equally.

\section{CONFLICTS OF INTEREST}

The author declares that there are no conflicts of interest regarding the publication of this paper.

\section{AUTHORS' FUNDING}

The financial aid extended by UGC in the form of Rajiv Gandhi National Fellowship for minority students is greatly appreciated.

\section{REFERENCES}

1. Haynes WM, Lide DR. CRC Handbook of Chemistry and Physics: A Ready-reference Book of Chemical and Physical Data. Boca Raton, Florida: CRC Press; 2011.

2. ATSDR. Toxicological Profile for Cadmium. Atlanta, Georgia: U.S. Department of Health and Humans Services, Public Health Service, Centers for Disease Control; 2003.

3. IARC. IARC Monographs on the Evaluation of Carcinogenic Risk to Humans, Cadmium. Lyon: IARC Press; 1993. p. 119-238.

4. EPA. Cadmium Compounds, Technology Transfer Network-air Toxics Web Site. Washington, DC, USA: EPA; 2007.

5. OEHHA. Chemicals Known to the State to Cause Cancer or Reproductive Toxicity. Safe Drinking Water and Toxic Enforcement Act of 1986. Office of Environmental Health Hazard Assessment. Sacramento, CA: California Environmental Protection Agency; 2005. Available from: http://www.oehha.ca.gov/prop65/prop65 list/021105list.html.

6. Sharma S, Kumari A. Protective effect of Curcuma longa administration on lung of mice exposed to cadmium. Asian J Pharm Clin Res 2018;11:536-39.

7. IPCS. Environmental Health Criteria 134. Geneva: World Health Organization; 1992.

8. Jarup L. Cadmium overload and toxicity. Nephrol Dial Transplant 2002;17:35-9.

9. Mannino D, Holguin F, Greves H, Savage-Brown A, Stock A, Jones R. Urinary cadmium levels predict lower lung function in current and former smokers: Data from the third national health and nutrition examination survey. Thorax 2004;59:194-8.

10. Stohs SJ, Bagchi D, Hassoun E, Bagchi M. Oxidative mechanisms in the toxicity of chromium and cadmium ion. J Environ Pathol Toxicol Oncol 2000;19:201-3.

11. ATSDR. Toxicological Profile for Cadmium. Atlanta, Georgia: U.S. Department of Health and Human Services, Public Health Service; 1999.

12. Verougstraete V, Lison D. Cadmium, lung, and prostate cancer: A systematic review of recent epidemiological data. J Toxicol Environ Health 2003;6:227-55

13. Sorahan T, Esmen N. Lung cancer mortality in UK nickel-cadmium battery workers, 1947-2000. Occup Environ Med 2004;61:108-16.

14. Suhartono E, Iskandar, Santosa PB. Ameliorative effects of different parts of gemor (Nothaphoebe Coriacea) on cadmium induced glucose metabolism alteration in vitro. Int J Pharm Pharm Sci 2015;7:17-20.

15. Nath J, Kalita B, Das G. Curcumin and its nanoformulations: A comprehensive overview for the management of diabetes complications. Int J Curr Pharm Res 2019;11:18-21.

16. SBarclay LR, Vinqvist MR, Mukai K, Goto $H$, Hashimoto $Y$, Tokunaga $\mathrm{A}$, et al. On the antioxidant mechanism of curcumin: Classical methods are needed to determine antioxidant mechanism and activity. Org Lett 2000;2:2841-3.

17. Kamel R, Hashim AA, Ali SA. Palliative effect of curcumin on Stzinduced diabetes in rats. Int J Pharm Pharm Sci 2014;6:558-63.

18. Montgomery R. Determination of glycogen. Arch Biochem Biophy 1957;67:378-81.

19. Zlatkis A, Zak B, Boyle AJ. A new method for the direct determination of serum cholesterol. J Lab Clin Med 1953:41:486-92.

20. Lowery OH, Roseburg NJ, Farr AL, Raudall RJ. Protein measurement with the folin-phenol reagent. J Biol Chem 1951;193:265-75.

21. Ballantine R, Barford DD. Detennination of metals. In: Colowick SP, Kaplan NO, editors. Methods in Enzymology. New York: Academic Press. Inc.; 1957. p. 1002.

22. Timbrell JA. Principles of Biochemical Toxicology. $2^{\text {nd }}$ ed. London: Taylor and Francis; 1991.

23. Nwachukwu KC, Asagba SO, Nwose C, Okoh MP. Radiation protection and anti-oxidative effects of garlic, onion and ginger extracts, X-ray exposed albino rats as model for biochemical studies. Afr J Biochem Res 2014;8:166-73.

24. Anderson H, Larsen S, Splid H, Christenson ND. Multivariate statistical analysis of organ weights in toxicity studies. Toxicology 1999;136:67.

25. Parasuraman S, Zhen KM, Banik U, Christapher PV. Ameliorative effect of curcumin on olanzapine-induced obesity in sprague-dawley rats. Pharmacogn Res 2017;9:247-52.

26. Noble T, Zingg JM, Paul L, Smith D, Meydani M. The effect of curcumin plus piperine on body weight and fat loss as well as on the plasma levels of inflammatory cytokines in obese mice. Nutrition 2013;10:29.

27. Bastaki SM, Ahmed MM, Zaabi AA, Amir N, Adeghate E. Effect of turmeric on colon histology, body weight, ulcer, IL-23, MPO and glutathione in acetic-acid-induced inflammatory bowel disease in rats. BMC Complement Altern Med 2016;16:72.

28. Assis RP, Arcaro CA, Gutierres VO, Oliveira JO, Costa PI, Baviera AM, et al. Combined effects of curcumin and lycopene or bixin in yoghurt on inhibition of LDL oxidation and increases in HDL and paraoxonase levels in streptozotocin-diabetic rats. Int J Mol Sci 2017;18:332-9.

29. Eriyamremu GE, Asagba SO, Onyeneke EC, Adaikpo MA. Changes in carboxypeptidas A, dipeptidase and $\mathrm{Na}+\mathrm{K}+$ ATPase activities in the intestine of rats orally exposed to different doses of cadmium. BioMetals 2005;18:1-6.

30. Brzoska MM, Moniuszko-Jakoniuk J, Jurczuk M, GalazynSidorczuk M. Cadmium turnover and changes of zinc and copper body status of rats continuously exposed to cadmium and ethanol. Alcohol Alcohol 2002;37:213-21

31. Desai KR, Moid N, Patel PB, Highland HN. Protective effect of Allium sativum on deltamethrin induced toxicity in reproductive tissues of male mice. Int J Pharm Sci Res 2015;6:1711-20.

32. Merali Z, Singhal R. Influence of chronic exposure to cadmium on hepatic and renal cyclic AMP-protein kinase system. Toxicology 1975;4:207-14.

33. Hodson PV. Temperature effects on lactate glycogen metabolism in zinc intoxicated rainbow trout Salmo gairdniri. J Fish Res Board Canada 1976;33:1393-7.

34. Rana SV, Prakash R, Kumar A, Sharma CB. A study of glycogen in the liver of metal-fed rats. Toxicol Lett 1985;29:1-4.

35. Purohit RK, Chakrawarti A, Bhartiya KM. Radiation and cadmium induced biochemical alterations in mouse kidney. Iran J Radiat Res 2007;5:125-30.

36. Novelli EL, Marques SF, Almeida JA, Diniz YS, Faine LA, Ribas BO. Toxic mechanism of cadmium exposure on cardiac tissue. Toxic Subs Mech 2000;19:207-17.

37. Sharma S, Vijaya P. Nephrotoxic effects of cadmium. Trends Life Sci 2015:4:352-7.

38. Sharma S, Vijaya P. Ameliorating potential of lycopene against cadmium toxicity of kidney of albino mice. Int J Adv Res 2015;3:766-70

39. Walaas O, Walaas W, Gronnerod O. Molecular events in the action of insulin on the cell metabolism; the significance of cyclic AMP dependent protein kinases. Acta Endocrinol Suppl 1974;191:93-129.

40. Ivanova-Chemishanska L. Dithiocarbamates. In: Toxicity of Pesticides, Health Aspects of Chemical Safety WHO Coperhagan. Geneva: World Health Organization; 1982. p. 158-69.

41. Heath AG. Water Pollution and Fish Physiology. Boca Raton: CRC Press; 1995.

42. Seo K, Choi MS, Jung UJ, Kim HJ, Yeo J, Jeon SM, et al. Effect of curcumin supplementation on blood glucose, plasma insulin, and glucose homeostasis related enzyme activities in diabetic $\mathrm{db} / \mathrm{db}$ mice. Mol Nutr Food Res 2008;52:995-4.

43. Chakrawarti A, Purohit RK, Agarwal M, Joshi P, Basu A, Bhartiya KM, et al. Modulation of radiation and cadmium induced biochemical changes in mouse kidney by Emblica officinales Linn. Iran J Radiat Res 2010;8:3-10

44. Wassermann M, Wassermann D, Aronovaski I. The effects organochlorine insecticides on serum cholesterol level in people occupationally exposed. Bull Environ Contam Toxicol 1970;5:368-72.

45. Yadav R, Jindal A, Goyal PK. Protective effect of diltiazem against cadmium induced biochemical changes in the brain of Swiss albino mice. Ann Neurosci 2005;12:37-40.

46. El-Demerdash FM, Yousef MI, Kedwany FS, Baghdadi HH. Cadmium induced changes in lipid peroxidation, blood hematology, biochemical parameters and semen quality of male rats: Protective role of Vitamin E and $\beta$-carotene. Food Chem Toxicol 2004;42:1563-71.

47. Kaoud HA, Kamel MM, Abdel-Razek AH, Kamel GM, Ahmed KA. Neurobehavioural, neurochemical and neuromorphological effects of 
cadmium in male rats. J Am Sci 2010;6:189-02.

48. Somade PM, Adnaik RS, Mohite SK, Magdum CS. Protective role of Cucumis melo against cadmium induced oxidative neurotoxicity in mice. Int J Univ Pharm Biosci 2014;3:269-79.

49. Babaknejad N, Moshtaghie AA, Nayeri H, Hani M, Bahrami S. Protective role of zinc and magnesium against cadmium nephrotoxicity in male Wistar rats. Biol Trace Elem Res 2016;174:112-20.

50. Purohit RK, Joshi PK, Basu A, Agarwal M, Chakrawati A, Bhartiya KM. Modulatory influence of Emblica officinalis Linn. On radiation and cadmium induced biochemical alterations in the brain of Swiss albino mice. Pharmacologyonline 2010;3:304-16.

51. Bacq M, Alexander P. Fundamentals of Radiobiology. New York: International Series of Monographs in Pure and Applied Biology: Modern Trends in Physiological Sciences, Pergamon; 1961.

52. Susan TA, Sobha K, Veeraiah K, Tilak KS. Studies on biochemical changes in the tissues of Labeo rohita and Cirrhinus mrigala exposed to fenvalerate technical grade. J Toxicol Environ Health Sci 2010;2:53-62.

53. Harper AJ, Rodwell VM, Mayes PA. Review of Physiological Chemistry. $16^{\text {th }}$ ed. Los. Altos, California: Large Medical Publication; 1977.

54. Hashish EA, Elgaml SA. Hepatoprotective and nephroprotective effect of curcumin against copper toxicity in rats. Indian J Clin Biochem
2016;31:270-7.

55. Eybl V, Kotyzova D, Bludovska M. The effect of curcumin on cadmiuminduced oxidative damage and trace elements level in the liver of rats and mice. Toxicol Lett 2004:151:79-85.

56. Sarvalkar PP, Walvekar MV, Shaikh NH. Effects of dietary curcumin on protein profile in mice submandibular glands during aging. Int J Curr Microbiol Appl Sci 2014;3:258-64.

57. Stohs SJ, Bagchi D. Oxidative mechanisms in the toxicity of metal ions. Free Radic Biol Med 1995;18:321-36.

58. Massadeh AM, Al-Safi SA, Momani IF, Al-Mahmoud M, Alkofahi AS. Analysis of cadmium and lead in mice organs effect of Nigella sativa $\mathrm{L}$. (black cumin) on the distribution and immunosuppressive effect of cadmium-lead mixture in mice. Biol Trace Elem Res 2007;115:157-67.

59. Sompamit K, Kukongviriyapan U, Donpunha W, Nakmareong S, Kukongviriyapan V. Reversal of cadmium-induced vascular dysfunction and oxidative stress by meso-2, 3-dimercaptosuccinic acid in mice. Toxicol Lett 2010;198:77-82.

60. Kukongviriyapan U, Pannangpetch P, Kukongviriyapan V, Donpunha W, Sompamit K, Surawattanawan P. Curcumin protects against cadmium-induced vascular dysfunction, hypertension and tissue cadmium accumulation in mice. Nutrients 2014;6:1194-208 